sailed from London to Persia and back with a substantial personal library cramping the living space below decks with him, or else he had a previous knowledgeable background in the literature of his day and of the classics and he knew how to bring both to bear when required.

University of London

$$
\text { Matteo A. Pangallo }
$$

doi:10.1093/notesj/gj1182 (C) The Author (2006). Published by Oxford University Press. All rights reserved. For Permissions, please email: journals.permissions@oxfordjournals.org

\section{THOMAS HEYWOOD AND THE WEREWOLVES: SOURCES FOR THE WITCHES OF LANCASHIRE}

I HAVE previously suggested that Henri Boguet's popular demonological treatise, Discours des Sorciers (Lyon, 1590), is a possible source for the 'severed hand' episode in The Witches of Lancashire (London, 1634) ${ }^{1}$ by Thomas Heywood and Richard Brome. ${ }^{2}$ Other supernatural episodes in the play, such as the metamorphoses into greyhounds and horses, have been identified as originating as evidence given at the 1633-4 trial at Lancashire. However, neither Boguet nor the trial transcripts offer a likely source for the scene where the witches, in the form of 'a company of hell-cats' (V.iii.75), attack the Soldier at the mill. In this article I will consider possible sources for this episode.

In his $\Gamma \nu \alpha \tau \kappa \epsilon \tau o \nu$, or, Nine Bookes of Various History Concerninge Women (London, 1624), Thomas Heywood includes the following passage as part of his discussion 'Of Witches

\footnotetext{
1 Although published under the title The Late Witches of Lancashire, it is clear from the running heads of the 1634 edition as well as contemporary accounts that the play was performed as The Witches of Lancashire: Herbert Berry, 'The Globe bewitched and El Hombre Fiel', Medieval and Renaissance Drama in England, i (1984), 211-30. All references to the play are from The Witches of Lancashire, ed. Gabriel Egan (London, 2002).

2 Brett D. Hirsch, 'Werewolves and Severed Hands: Webster's The Duchess of Malfi and Heywood and Brome's The Witches of Lancashire', $N \& Q$, ccli (2006), 92-4.
}

that haue eyther changed their owne shapes, or transformed others':

Concerning Lycantropia, or men that change themselues into Wolues, Doctor Bordinus (generall Procurator for the king) relates, That a Wolfe setting vpon a man, hee shot him with an arrow through the thigh: who being wounded, and not able to plucke out the shaft, fled to his house, kept his bed, being found to be a man, and the arrow after knowne by him that shot it, by the Lycantropies confession. Those that are the diligent Inquisitor after Witches, report in a booke intituled Malleum Maleficarum, That a countreyman was violently assaulted by three great Cats, who in the defence of himself wounded them all dangerously; and these were knowne to be three infamous Witches, who were after found bleeding, and by reason of their hurts, in great danger of death. ${ }^{3}$

'Bordinus' is most likely a reference to Gilles Bourdin, Attorney General under Henri II, whose werewolf story is related by Jean Bodin in his chapter on lycanthropy in De la Demonomanie des Sorciers (Paris, 1580) as follows:

Il me souuient que M. le Procureur general du Roy Bourdin m'en a recité vn autre, qu'on luy auoit enuoyé du bas pays, avec tout le procés signé du Iuge \& des Greffiers, d'vn loup qui fut frappé d'vn traict en la cuisse, \& depuis se trouue en son lict auec le traict, qui luy fut arraché esta[n]t recha[n]gé en forme d'ho[m]me, \& le traict cogneu par celuy qui l'auoit tiré, le te[m]ps, \& le lieu iustifié par la co[n]fessio[n] du personage.

(I recall that the King's General Prosecutor, Master Bourdin, recounted another case to me, which had been sent to him from the Low Countries, with the whole trial summary signed by the judge and the court clerks. It concerned a werewolf who was wounded in the thigh by an arrow, and who later was found in his bed with the arrow

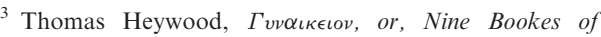
Various History Concerninge Women (London, 1624), 410.
} 
which was pulled out of him, now that he was changed back into the form of a man; and the arrow was recognised by the one who had shot it, and the time and place was confirmed by the person's confession. ${ }^{4}$ )

Heywood's passage also refers to the infamous Malleus Maleficarum (Speyer, 1486-7) of Heinrich Kramer and Jacob Sprenger. According to the Malleus, the event took place in 'a town in the diocese of Strasburg', when one day

A labourer was cutting wood there to burn (at home), all of a sudden a certain cat of large size strove to harass him by throwing itself against him insistently. When he cast the cat aside, another one of greater size all of a sudden appeared, accosting him more vigorously along with the first one. When he again tried to push them away, there now were three of them accosting him together, sometimes jumping at his face, sometimes snapping at his forearms... he was barely able to drive the hostile cats off, striking them with the cut wood, first one on the head, then another on legs or back, as they leaped up, one moment at his face, the next at his throat. ${ }^{5}$

Having beaten the cats away, the labourer returns to his work only to be arrested for wounding 'three prominent matrons of this city, so that they lie in their beds and cannot get up or move'. The labourer, understandably confused, swears that he has never struck a woman in his life, but recalls that earlier he had 'struck creatures, but they were not women'. The judge, realizing the actual nature of the events, promptly releases the labourer, who is under strict instruction 'to reveal the affair

\footnotetext{
4 Jean Bodin, De la Demonomanie des Sorciers (Paris, 1580), $97^{\mathrm{r}}$. The translation is taken from On the DemonMania of Witches, trans. Randy A. Scott (Toronto, 1995), 123. All further references are to this translation and are cited parenthetically in the text.

${ }^{5}$ The translation is taken from Malleus Maleficarum: The Hammer of Witches, ed. Christopher S. Mackay (Cambridge, 2006), 123D-125C. All subsequent references are to this edition and section of the text. I thank Professor Mackay for generously providing me advance access to his translation for the purpose of this article.
}

to no one', presumably on account of the prominence of the women involved.

Although Heywood refers to the Malleus as the source of this story, there is evidence to suggest that he had no direct access to the original version, but instead borrowed the anecdote indirectly from Bodin, who repeats the story of "three witches near Strasbourg who attacked a labourer in the guise of three great cats', the labourer, 'in defending himself ... wounded and chased off the cats who were found ailing in bed in the form of badly wounded women at that very moment' (124). ${ }^{6}$ Heywood's version is much more closely aligned to Bodin's, since both immediately identify the perpetrators as known to be witches, whereas the Malleus only reveals the woman as 'three prominent matrons' and the event as 'the work of the demon'.

Heywood read Bodin in Latin translation, ${ }^{7}$ since no English translation was available and there is little to suggest that he read French. ${ }^{8}$ In any case, Heywood makes clear that his knowledge is not always gathered first-hand, incorporating 'such things as [he] haue eyther read, or heard related' (409). Thus it is certainly possible that Heywood relied on both in transforming continental reports of supernatural violence into stage spectacle in

\footnotetext{
6 'Mais les cinq Inquisiteurs qui estoient experimentez en telles causes ont laissé par écript qu'il y eut trois Sorciers pres Strasbourg, qui assaillirent vn Laboureur en guise de trois grans chats, \& en se defendant il blessa \& chassa les chats, qui se trouuerent au lict malade en forme de femmes fort blessees à l'insta[n]t mesme: \& sur ce enquises elle accusere[n]t celuy qui les auoit frappees, qui dict aux Iuges, l'heure, \& le lieu, qulil auoit esté assailly de chats, \& qu'il les auoit blessez' $\left(97^{\mathrm{v}}\right)$.

7 Bodin's treatise was popular across continental Europe, and was available in numerous Latin, German, and Italian editions that were published shortly after the French original. Heywood's chapter 'Of Witches' begins with a reference to 'Iohannes Bodinus, Andegauensis lib. 3. cap. 3. de Magorum Demonomania' (399), and all subsequent references are to this edition and Latinized form.

${ }^{8}$ W. Bang, Pleasant Dialogues and Dramma's Von Tho. Heywood,. Materialien Zur Kunde Des Älteren Englischen Dramas, Vol. 3 (Louvain, 1903), 339; and R. G. Martin, 'A Critical Study of Thomas Heywood's Gunaikeoin', SP, xx (1923), 160-83, 175. Compare Arthur C. Clark, 'Thomas Heywood's The Rape of Lucrece [Review]', RES, n.s. iii, 11 (1952), 285-9.
} 
The Witches of Lancashire: locating a story of 'hell-cats' (V.iii.75) in his reading of Bodin, and perhaps coming to the 'severed hand' tale of Boguet's by word of mouth.

University of Western Australia

Brett D. Hirsch

doi:10.1093/notesj/gj1183

(C) The Author (2006). Published by Oxford University Press.

All rights reserved. For Permissions,

please email: journals.permissions@oxfordjournals.org

\section{EARLY MODERN ENGLISH 'BACK': EROTIC USES}

IN Renaissance English, the human back appears to have had obscure sexual meanings that were lost in later times. In a vague and more general form, back could stand for something like 'sexual prowess', an aspect which will be discussed later. My chief objective in the present note is to examine the term in the sense of 'penis' (or 'phallus'). This particular semantic facet of back (sometimes also spelled beck) has, as far as I am aware, not found its way into historical dictionaries and textbooks. The evidence, however, is unmistakable.

Perhaps Italian becco 'beak' influenced the formation of such a specific meaning of the English word. Though the Italian expression is not as explicit as the English one, it occasionally, too, seems to have carried erotic overtones. John Florio, in his Italian-English dictionary (1598), mentions 'cuckold' for becco, ${ }^{1}$ and a modern historical dictionary of Italian phrases glosses becco as 'penis' and quotes the idioms beccare l'oca and mettere il becco a bagno 'coire'. ${ }^{2}$ Becco and oca (goose), we are told, were generally conceived as male and female symbols, particularly in humorous texts (ibid.). In Early Modern English, goose is a partially sexualized term, too. Shakespeare famously alludes to 'some galled goose of Winchester' (a syphilitic Bankside

\footnotetext{
1 John Florio, A Worlde of Wordes (1598), new edn: Queen Anna's New World of Words, or Dictionarie of the Italian and English tongues (London, 1611, rpt. Menston: Scolar Press, 1968), s.v. bécco (58).

2 Ottavio Lurati, Dizionario dei modi di dire (Milano: Garzanti, 2001), s.v. becco (68-9).
}

prostitute - Troilus and Cressida, V.x.54; cf. 1 Henry VI, I.iii.53), ${ }^{3}$ and goose is sometimes understood as 'light woman' or implicitly even 'female sexual organ' in the author's plays (fat goose, green goose, wild goose, sweet goose, broad goose - see Love's Labours Lost, III.i.84-122 and IV.iii.73, and Romeo and Juliet, II.iv.71-87). ${ }^{4}$

The noun back in the sense of 'penis,' perhaps conflated with words like beak, pecker, pick, and pike, occurs chiefly in Tudor and Stuart texts. The latest case which has come to my knowledge is in the Earl of Rochester's poems, c. 1672.

1. In William Shakespeare's comedy The Merry Wives of Windsor (1598), Falstaff prays for success in his amorous encounters: 'Now, the hot-blooded gods assist me!....(O Jove, a beastly fault!).... When gods have hot backs, what shall poor men do?' (V.v.2-12). ${ }^{5}$

2. In John Marston's tragdy The Malcontent (c. 1603), the 'Matchevill' Mendoza kills Ferneze, who is coming in his shirt from the Duchess Aurelia's bed, and shouts triumphantly: 'Thou shallow fool, drop there! / He that attempts a princess' lawless love / Must have broad hands, close heart, with Argus' eyes, / And back of Hercules, or else he dies' (II.v.5-8). ${ }^{6}$

\footnotetext{
${ }^{3}$ Shakespeare's works are quoted from The Riverside Shakespeare, ed. G. Blakemore Evans, 2 vols (Boston: Houghton Mifflin, 1974). A 'Winchestrian goose' with the fire of venereal disease 'locked up' inside her, figures also in Ben Jonson's poem 'An Execration upon Vulcan' (1623, line 142); see B. Jonson, The Complete Poems, ed. George Parfitt (Harmondsworth: Penguin, 1975), 181-7.

4 On the 'goose image cluster,' see Johannes Fabricius, Syphilis in Shakespeare's England (London: J. Kingsley, 1994), 214-23; compare also H. Breuer, 'Shakespeare's "humble-bee": a note on Troilus and Cressida, 5.10.41-44', Revue des langues vivantes, xliii (1977), 380-3. In the puns and innuendoes of Tudor, Stuart, and Restoration plays, stewed prunes and oranges also carry sexual implications which are difficult to grasp for modern readers.

5 Eric Partridge glosses indirectly: have a hot back - 'to be lecherous or amorous' (Shakespeare's Bawdy (London: Routledge and Kegan Paul, 1947, rev. edn 1968), s.v. back, 60). No other instances are given.

6 John Marston, The Malcontent, ed. M. L. Wine, Regents Renaissance Drama Series (London: Arnold, 1965), 51.
} 